\title{
Identification and Characterization of Large Plasmids in Rhizobium meliloti using Agarose Gel Electrophoresis
}

\author{
By FRANCINE CASSE, C. BOUCHER, J. S. JULLIOT, \\ M. MICHEL AND J. DÉNARIÉ \\ Laboratoire de Génétique des Microorganismes, I.N.R.A., \\ Route de Saint-Cyr, 78000 Versailles, France
}

(Received 23 October 1978)

The use of a modified procedure for the isolation of covalently closed circular DNA of high molecular weight, followed by agarose gel electrophoresis of the crude extracts, provides a simple screening method for detecting plasmids with molecular weights of more than $250 \times 10^{6}$ from Agrobacterium tumefaciens, Pseudomonas putida and Rhizobium species. This method was used for a survey of plasmids in 25 symbiotically effective strains of Rhizobium meliloti from various geographical origins. Of these, 22 strains were found to carry at least one large plasmid. By electron microscopy and measurement of electrophoretic mobility in gels, the molecular weights of most of the plasmids were estimated to range from $90 \times 10^{6}$ to $200 \times 10^{6}$.

\section{INTRODUCTION}

At present, the Rhizobium-legume symbiosis is clearly the most efficient system for nitrogen fixation by cultivated plants. Lucerne is, with soybean, the crop which provides the largest amount of fixed nitrogen throughout the world (Hanson, 1972). Tools required for the genetic analysis of the symbiotic properties of Rhizobium meliloti, the bacterial partner of lucerne, are now available: these include the isolation of numerous mutants (Dénarié et al., 1976; Meade \& Signer, 1977; Kondorosi et al., 1977), specialized transduction (Sváb et al., 1978), generalized transduction (Kowalski, 1970), introduction of bacteriophage $\mathrm{Mu}$ (Boucher et al., 1977) and $\mathrm{P}$ plasmid-mediated conjugation (Kondorosi et al., 1977; Meade \& Signer, 1977). No gene controlling symbiotic properties such as host specificity, nodule-inducing ability and nitrogen fixation has yet been mapped on the $R$. meliloti chromosome.

The family Rhizobiaceae contains only two genera, Agrobacterium and Rhizobium. The bacteria of both genera are able to induce cell multiplication of host plants. Agrobacterium tumefaciens and Agrobacterium rubi induce tumours in different families of dicotyledonous plants, Agrobacterium rhizogenes promotes root proliferation at wound sites, while Rhizobium species induce nodule formation on the roots of specific leguminous plants. The tumour-inducing ability of $A$. tumefaciens is controlled by large plasmids (Van Larebeke et al., 1974; Watson et al., 1975; Sciaky et al., 1978) having molecular weights ranging from $98 \times 10^{6}$ to $158 \times 10^{6}$. Such large plasmids have also been found in $A$. rhizogenes and $A$. rubi (Sciaky et al., 1978).

Procedures have been devised for the isolation of large covalently closed circular DNA molecules (CCC-DNA) in A. tumefaciens (Zaenen et al., 1974; Currier \& Nester, 1976; Ledeboer et al., 1976). Using the Ledeboer et al. (1976) procedure, Nuti et al. (1977) detected large plasmids in six strains of Rhizobium leguminosarum, Rhizobium trifolii, Rhizobium japonicum and Rhizobium 'cowpea' by sedimentation analysis of lysates on alkaline sucrose gradients and by buoyant density gradient centrifugation. As estimated by 
renaturation kinetics, the molecular weights of these plasmids were in the range $70 \times 10^{6}$ to $400 \times 10^{6}$.

In this paper we report (i) evidence from electron microscopy for the presence of plasmids of molecular weights greater than $90 \times 10^{6}$ in several $R$. meliloti strains, (ii) a simple method allowing rapid detection and characterization of such plasmids by agarose gel electrophoresis and (iii) a screening for large plasmids among 25 symbiotically effective strains of $R$. meliloti chosen because of their varied geographical origin, previous genetic studies and agricultural importance for lucerne seed inoculation.

\section{METHODS}

Bacterial strains. These are listed in Table 1. The plasmid RP4 (Datta et al., 1971) was introduced into R. meliloti L 5-30 str-1 as described by Boucher et al. (1977).

Media and growth conditions. Rhizobium meliloti strains were grown in the complex medium described by Boucher et al. (1977) from which mannitol was omitted (medium $\mathrm{CMtl}^{-}$). Rhizobium trifolii and $R$. leguminosarum strains were grown in TY medium (Beringer, 1974), A. tumefaciens in nutrient broth and Pseudomonas putida in B broth (Boucher et al., 1977). Liquid cultures were incubated with shaking at $28^{\circ} \mathrm{C}$.

Plant inoculation tests. Symbiotic properties of $R$. meliloti strains were checked on alfalfa seedlings (variety Milfeuil) grown aseptically on nitrogen-free agar slants in test tubes as described by Vincent (1970). Two seedlings were sown in each tube, and tubes were inoculated with about $10^{7}$ bacteria 1 week after sowing. Acetylene reduction was measured 4 weeks after inoculation on whole plants in each test tube, using a Girdel 75B gas chromatograph and a Porapak T column.

DNA isolation procedures.

(i) Preparation of crude lysates for agarose gel electrophoresis. Only the final procedure is described here; each of the major steps is discussed in more detail in Results and Discussion. To avoid an excess of polysaccharides, bacteria were grown in $50 \mathrm{ml}$ of a medium containing yeast extract, Casamino acids or peptones but no additional carbon source such as sugars or polyols. They were harvested before the end of the exponential phase. Then $\mathrm{NaCl}$ was added at $1 \mathrm{~m}$ final concentration and the culture was shaken vigorously for $30 \mathrm{~min}$. Bacteria were washed twice with TE buffer pH 8 (Tris, $0.05 \mathrm{M}$; EDTA, $0.02 \mathrm{M}$ ) and the pellet obtained was weighed and suspended in TE buffer $\mathrm{pH} 8(100 \mathrm{mg}$ bacteria to $0.5 \mathrm{ml}$ buffer, for better reproducibility). The lysing buffer [TE buffer containing $1 \%(\mathrm{w} / \mathrm{v})$ sodium dodecyl sulphate] was adjusted to pH 12.45 with a numerical pH-meter Model Minisis 6000 (Tacussel, France) previously standardized to pH 12.45 with a Beckman Standard pH 12.45 buffer. To $0.5 \mathrm{ml}$ bacterial suspension in a $50 \mathrm{ml}$ beaker, $9.5 \mathrm{ml}$ of the lysing buffer was added and the mixture was stirred with a magnetic stirrer at $100 \mathrm{rev} . \mathrm{min}^{-1}$ for $90 \mathrm{~s}$ before incubation at $34^{\circ} \mathrm{C}$ for 20 to $25 \mathrm{~min}$. The $\mathrm{pH}$ was then lowered to 8.5 to 8.9 by adding $0.6 \mathrm{ml}$ $2 \mathrm{M}$-Tris buffer $\mathrm{pH} 7 \cdot 0$ and stirring the mixture at $100 \mathrm{rev}$. $\mathrm{min}^{-1}$ for $2 \mathrm{~min}$. The lysate was adjusted to $3 \%(\mathrm{w} / \mathrm{v}) \mathrm{NaCl}$ and after $30 \mathrm{~min}, 10 \mathrm{ml}$ phenol [previously saturated with a solution of $3 \%(\mathrm{w} / \mathrm{v}) \mathrm{NaCl}$ in water] was added. The two phases were mixed by stirring at $300 \mathrm{rev} . \mathrm{min}^{-1}$ for $10 \mathrm{~s}$ and further stirred for $2 \mathrm{~min}$ at $100 \mathrm{rev} \cdot \mathrm{min}^{-1}$. The mixture was then centrifuged at $5000 \mathrm{~g}$ for $10 \mathrm{~min}$ and the clear aqueous upper phase was transferred, using an inverted pipette, into a sterile Corex tube (Poly-Labo, Strasbourg, France). It was brought to $0 \cdot 3 \mathrm{M}$-sodium acetate and 2 vol. cold $\left(-20{ }^{\circ} \mathrm{C}\right) 95 \%(\mathrm{w} / \mathrm{v})$ ethanol was added to precipitate the DNA. The tube was kept at $-20^{\circ} \mathrm{C}$ overnight. The precipitated DNA was recovered by centrifuging at $12000 \mathrm{~g}$ at $-10^{\circ} \mathrm{C}$ for $20 \mathrm{~min}$. The ethanol was removed from the tube and the DNA pellet was dissolved in $100 \mu \mathrm{l}$ TES buffer pH 8.0 (Tris, $0.05 \mathrm{~m}$; EDTA, $0.005 \mathrm{M}$; NaCl, $0.05 \mathrm{M}$ ). The tubes were held under vacuum for $5 \mathrm{~min}$ to remove residual ethanol. The DNA sample was analysed immediately by agarose gel electrophoresis or stored at $-20^{\circ} \mathrm{C}$ until ready for use.

(ii) Large-scale isolation. In the first experiments, large plasmid DNA was prepared from 11 cultures according to the method of Currier \& Nester (1976). This procedure was then modified to allow isolation of very large CCC-DNA molecules as in the micro-scale method described above: lysis was performed in alkaline buffer; DNA was precipitated with $0.3 \mathrm{M}$-sodium acetate and resuspended in $2 \mathrm{ml}$ TES buffer. DNA was purified by $\mathrm{CsCl}$-ethidium bromide $(\mathrm{EtBr})$ equilibrium density gradient centrifugation (Radloff et al., 1967) carried out for $48 \mathrm{~h}$ in a fixed angle Ti 50 rotor at $36000 \mathrm{rev} \cdot \min ^{-1}$ and $20^{\circ} \mathrm{C}$. The CCC-DNA band was visualized under ultraviolet (u.v.) light and removed with a syringe. Ethidium bromide was eliminated from the sample by extraction with isopropanol saturated with a $3 \mathrm{M}-\mathrm{NaCl}$ and $0.3 \mathrm{M}$-sodium citrate buffer (M. Van Montagu, personal communication). After dialysis, the DNA concentration was measured by u.v. absorption at $260 \mathrm{~nm}$ (Humphreys et al., 1975). 
Table 1. Bacterial strains

Bacterial species and geographical origin

\begin{tabular}{|c|c|}
\hline Rhizobium meliloti & \\
\hline South Africa & Rf22 \\
\hline North America & \\
\hline Canada & 12 \\
\hline & Balsac, S14, 54032, I1, V7 \\
\hline U.S.A. & 3DoA20a \\
\hline & $\mathrm{S} 26 \dagger$ \\
\hline & $\mathrm{S} 33 \dagger, 102 \mathrm{~F} 28 \dagger, 102 \mathrm{~F} 51 \dagger$ \\
\hline South America & \\
\hline Argentina & B251 \\
\hline Uruguay & $\mathrm{U} 45 \dagger$ \\
\hline & U54 \\
\hline Europe & \\
\hline France & Lb1, Ls2a, Ve8 \\
\hline & Sa10† \\
\hline Hungary & 41 \\
\hline Netherlands & A145 \\
\hline Poland & L5-30 \\
\hline & L5-30 str-1 (RP4) \\
\hline Sweden & 311 \\
\hline Oceania & \\
\hline Australia & RCR2011 (= SU47) $\dagger$ \\
\hline & RCR2011 str-3 (RP4) \\
\hline New Zealand & 1322 \\
\hline R. leguminosarum & \\
\hline & LPR 115 \\
\hline & A171 \\
\hline & LPR180 \\
\hline
\end{tabular}

R. trifolii

A. tumefaciens

RCR5
B. W. Strijdom (PPRI, Pretoria)

E. B. Roslycky (Agriculture Canada, Ontario)

Bordeleau et al. (1977)

D. Weber (USDA, North Dakota)

Agricultural Laboratories (Ohio)

J. C. Burton (Nitragin Co., Milwaukee)

E. de Olivero (I.N.T.A., Argentina)

Brockwell \& Hely (1966)

M. de Bertalmio (M.G.Y., Montevideo)

M. Obaton (I.N.R.A., Montpellier)

Gasser et al. (1972)

Kondorosi et al. (1977)

D. A. van Schreven (I.L.P.D.C.A., Kampen)

Kowalski (1970)

This paper

H. Ljunggren (Agricultural College, Uppsala)

Brockwell \& Hely (1966)

Boucher et al. (1977)

A. Hastings (D.S.I.R., Auckland)

Prakash et al. (1979)

Prakash et al. (1979)

Prakash et al. (1979)

Nuti et al. (1977)

Van Larebeke et al. (1974)

Bomhoff et al. (1976)

Sciaky et al. (1978)

\section{J. Shapiro (Chicago University)}

J. Shapiro (Chicago University)

* Rhizobium meliloti strains Rf22, 12, B251, U45, U54, A145, 311 and 1322 were provided by M. Obaton (I.N.R.A., Montpellier, France), 3DoA20 a, S26, S33 by L. M. Bordeleau (Agriculture Canada, Quebec, Canada), 102F51 by H. Meade (Harvard University, U.S.A.) and 102F28 by E. W. Nester (Seattle, U.S.A.). Agrobacterium tumefaciens strains were provided by J. Schell (Gent University, Belgium). Rhizobium leguminosarum and $R$. trifolii strains were provided by P. J. J. Hooykaas (Leiden University, The Netherlands).

$\dagger$ Rhizobium meliloti strains used in commercial inoculants.

Agarose gel electrophoresis of DNA. Electrophoresis was carried out in a vertical lucite slab gel apparatus, with $100 \times 140 \times 3 \mathrm{~mm}$ gels. Sample wells were prepared with lucite combs having ten or six teeth. The power source was an Isco electrophoresis power supply Model 393 (Lincoln, Nebraska, U.S.A.). The method described by Meyers et al. (1976) for CCC-DNA was used. Electrophoresis was performed in $0.7 \%(\mathrm{w} / \mathrm{v})$ agarose (Sigma) at $5 \mathrm{~V} \mathrm{~cm}^{-1}$.

Gels were visualized on an Ultra-violet Products transilluminator model C61. Photographs were taken with Polaroid, type 55 positive/negative $4 \times 5$ Land film using a no. 4 Wratten gelatin filter (Kodak). Relative mobility in agarose gel electrophoresis was measured on photographic enlargements of gels $(21 \times 29 \mathrm{~cm})$. At least three different gels were run for each strain. Plasmids pRme-L5-30 and RP4 were used as controls in each gel; the mobility of plasmid pRme-L5-30 was set arbitrarily at 10. For estimation of the relative amounts of the different plasmid forms, photographic negatives of the gels were studied with a Gelman densitometer (Ann Arbor, U.S.A.) model DCD-16. 
Electron microscopy of DNA. The contour length of plasmid DNA was determined as described by Zaenen et al. (1974) with the fcllowing modifications (G. Engler \& M. Van Montagu, personal communication). The DNA sample was dialysed against 0.01 M-Tris, 0.001 M-EDTA buffer pH 8.0. Dialysed samples (usually $1 \mu \mathrm{l}$ ) were spread on to $0.25 \mathrm{M}$-ammonium acetate $(\mathrm{pH} 7 \cdot 5)$; the spreading solution $(60 \mu \mathrm{l})$ contained

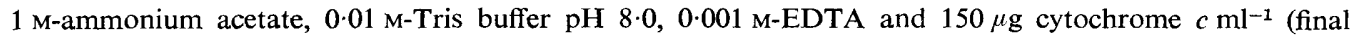
concentration). After rotary shadowing with Pt/Pd (Polaron Equipment, Watford; ref. 1264), grids were examined in a Philips EM300 electron microscope. The magnification was determined by photographing a grating replica (54800 lines in ${ }^{-1}$; Polaron, ref. 0736). Tracings of open circular molecules of plasmid DNA were measured with a GTCO Corporation Electronic Graphics Calculator and a Hewlett-Packard 9825 A Calculator. Molecular weights were calculated from the contour lengths by using the conversion factor of $1 \mu \mathrm{m}=2.07 \times 10^{6}$.

Plasmid nomenclature. To conform to the designations used by Sciaky et al. (1978) for Iarge cryptic plasmids from strains of $A$. tumefaciens, which is also a member of the family Rhizobiaceae, we designated the naturally occurring $R$. meliloti, $R$. trifolii and $R$. leguminosarum plasmids $\mathrm{pRme}$, pRtr and pRle, respectively, followed by the strain number in which the plasmid was found and serial letters in cases of multiple plasmids.

\section{RESULTS AND DISCUSSION}

\section{Isolation of CCC-DNA of high molecular weight in R. meliloti}

The preparative isolation procedure for large CCC plasmid DNA molecules described by Currier \& Nester (1976) was used first with four symbiotically effective strains of R. meliloti for which genetic markers are available: L5-30 and Sa10 (Dénarié et al., 1976), RCR2011 (Meade \& Signer, 1977) and 41 (Kondorosi et al., 1977). After ultracentrifugation in $\mathrm{CsCl}-\mathrm{EtBr}$ density gradients, two fluorescent bands were clearly seen under u.v. irradiation for strains L5-30 and 41. The amount of DNA in the lower band was 20 to $80 \mu \mathrm{g}$. When this was examined electron microscopically, supercoiled and open circular molecules were observed. The contour lengths were $43 \cdot 7 \pm 1 \cdot 1 \mu \mathrm{m}$ for pRme-L5-30 and $67 \cdot 5 \pm 2 \cdot 8 \mu \mathrm{m}$ for pRme-41, corresponding to molecular weights of $91 \times 10^{6}$ and $140 \times 10^{6}$, respectively. Only the upper band could be seen for strains RCR 2011 and Sa10. These results were very reproducible: four independent experiments showed a clear CCC-DNA band for L5-30 and 41 and only the 'upper' band for RCR2011 and Sa10. From density gradients containing RCR2011 and Sa10 DNA, samples were withdrawn at the position expected for supercoiled DNA, then dialysed and examined by electron microscopy. Even for samples 40 times larger than in the case of L5-30 and 41, no circular DNA could be observed. We were not sure whether the apparent lack of CCC-DNA in strains RCR2011 and Sa10 reflected a true lack of extrachromosomal elements or was due to a limitation of the Currier \& Nester procedure for isolation of CCC plasmid DNA of molecular weight higher than $160 \times 10^{6}$.

\section{A simple procedure for obtaining crude extracts of large plasmid CCC-DNA}

Our aim was to estimate the frequency of occurrence of large plasmids in $R$. meliloti. We therefore required a method suitable for screening for plasmids in a large number of strains and which could detect plasmids of molecular weight higher than $150 \times 10^{6}$.

Meyers et al. (1976) have described a method for rapid detection and identification of plasmids based on agarose gel electrophoresis of DNA crude extracts. However, neither the sodium dodecyl sulphate-salt precipitation method (Guerry et al., 1973) used for preparation of these crude extracts, nor the cleared lysate procedure (Clewell \& Helinski, 1969) allow efficient isolation of large plasmid DNA from Agrobacterium (Zaenen et al., 1974; Currier \& Nester, 1976; Ledeboer et al., 1976) and Rhizobium (Nuti et al., 1977).

In preliminary experiments, CCC-DNA of the large plasmids from strains L5-30 and 41 were found to migrate through agarose gel during electrophoresis in spite of their high molecular weights. We therefore modified the Currier \& Nester (1976) procedure for isolating CCC-DNA in an attempt to make it more suitable for handling a large number of small volume cultures and to allow the detection of larger plasmids by decreasing DNA shearing. 
Alkaline cell lysis and denaturation of DNA. To obtain supercoiled DNA of plasmids of molecular weight higher than $150 \times 10^{6}$ we had to limit DNA shearing. In the Currier \&

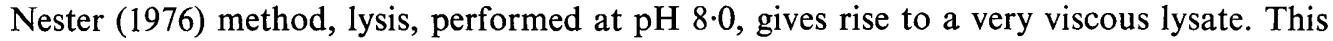
lysate has to be sheared by passage through a syringe or in a mixer to decrease its viscosity and allow the added $\mathrm{NaOH}$ solution to have access to the DNA thus providing alkaline denaturation. This shearing, which is a very critical step, could be responsible for an important variation in the recovery of large CCC-DNA molecules (Currier \& Nester, 1976). If lysis is carried out in an alkaline buffer at the $\mathrm{pH}$ used for denaturation (around 12.3), the viscosity of the lysate is low and shearing is not required. In addition, lysis in highly alkaline buffer provides a protein denaturation effect which may serve to reduce the enzymic degradation of plasmid DNA. Alkaline denaturation was achieved by adding a constant volume of an alkaline lysing buffer ( $\mathrm{pH} 12.45$ at $25^{\circ} \mathrm{C}$ and $1 \%$ sodium dodecyl suphate) to a small volume corresponding to a constant weight of bacterial suspension. This modification limits the use of a $\mathrm{pH}$-meter to the initial preparation of the lysing buffer. It thus provides better reproducibility, time saving and decreased DNA shearing. Denaturation is a very critical step. For a given species (characterized by its GC content), the efficiency of removal of chromosomal DNA increases with pH (Figs 1 and 3, lanes A and B) but CCC-DNA recovery also decreases. For Rhizobium and Agrobacterium strains the optimal $\mathrm{pH}$ of the lysing buffer is 12.45 (at $25^{\circ} \mathrm{C}$ ). Adjustment of the lysing buffer to $\mathrm{pH} 12.45$ has to be carried out carefully with electrodes resistant to Tris and to alkaline $\mathrm{pH}$ and calibrated

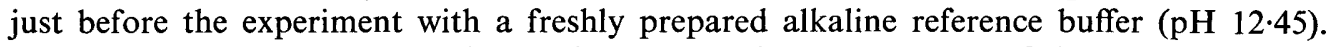
At such high $\mathrm{pH}$, temperature is very important; the temperatures of the reference buffer and of the lysing buffer have to be exactly the same. Incubation for $25 \mathrm{~min}$ was required to achieve good lysis. Incubation at $34^{\circ} \mathrm{C}$ provided better lysis than at 10 or $20^{\circ} \mathrm{C}$. Incubation for longer than 30 min decreased the yield of plasmid DNA.

Removal of denatured DNA and proteins. Denatured DNA was precipitated by adjusting the lysate to $3 \%$ (w/v) NaCl followed by extraction with phenol (Currier \& Nester, 1976). After addition of phenol saturated with a solution of $3 \% \mathrm{NaCl}$, both phases were mixed by stirring for 10 to $15 \mathrm{~s}$ at $300 \mathrm{rev}$. $\mathrm{min}^{-1}$ and then for 2 to $5 \mathrm{~min}$ at $100 \mathrm{rev}$. $\mathrm{min}^{-1}$ (minimal rotation to avoid separation of the two phases). For plasmids of molecular weight up to $150 \times 10^{6}$, a $5 \mathrm{~min}$ phenol extraction gave good CCC-DNA recovery. For plasmids of higher molecular weight (for instance in strains V7, Sa10 and Lb1; see below), no CCC-DNA could be detected after a 5 min phenol extraction. A shorter phenol extraction of 2 min allowed CCC-DNA recovery for these large molecules, but this incomplete phenol treatment can provide extracts which cause a deformation of the top of the agarose gel during electrophoresis (see Fig. 1, lanes C and D).

Concentration of DNA. In this microprocedure, ethanol precipitation with magnesium phosphate (Currier \& Nester, 1976) gave rise to large pellets which took a long time to dissolve in the small volumes required for agarose gel electrophoresis. Precipitation with $0.3 \mathrm{M}$-sodium acetate and $2 \mathrm{vol}$. ethanol (Meyers et al., 1976) produced pellets that were easier to resuspend in $100 \mu \mathrm{l}$ TES buffer.

The above extraction procedure can be performed within $8 \mathrm{~h}$ by one person on 20 to 40 strains. In addition, as shown below, it allows extraction of CCC-DNA molecules of molecular weights higher than $300 \times 10^{6}$.

\section{Agarose gel electrophoresis of large plasmids}

The initial electrophoresis experiments were done with strains carrying large plasmids of known molecular weights: A. tumefaciens C58 with pTi-C58 $\left(120 \times 10^{6}\right)$ (Watson et al., 1975), A. tumefaciens B6-806 with two plasmids of $125 \times 10^{6}$ (Sciaky et al., 1978), R. meliloti 41 with pRme-41 $\left(140 \times 10^{6}\right)$ and $R$. meliloti L5-30 (RP4) carrying two plasmids pRmeL5-30 $\left(91 \times 10^{6}\right)$ and RP4 $\left(36 \times 10^{6}\right)$. On these gels, as on those described below (Figs 1 to 4), fluorescence was distributed in three regions as described by Meyers et al. (1976): an 


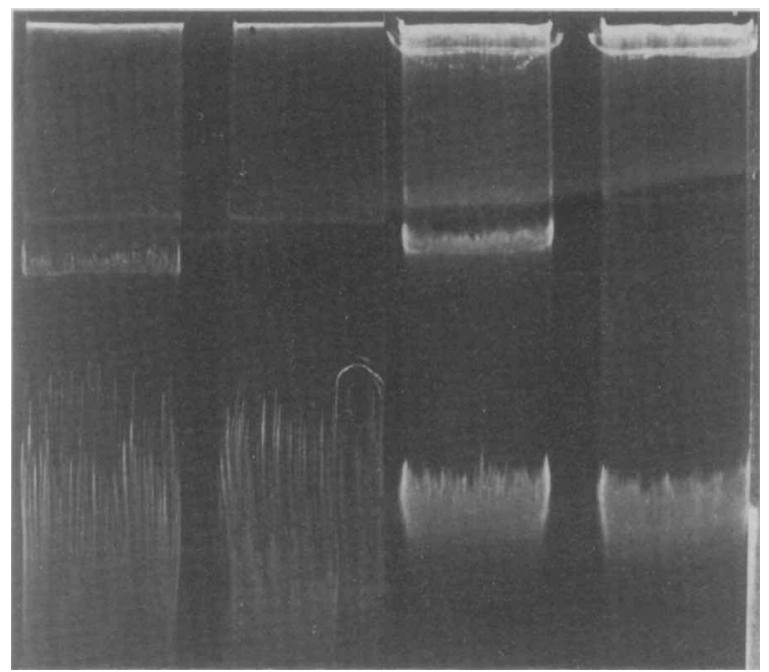

Fig. 1. Agarose gel electrophoresis of ethanol-precipitated DNA from crude lysates. (A) Lysate from $A$. tumefaciens strain C58 showing in addition to the Ti plasmid (lower band) a very large cryptic plasmid, pAt-C58. (B) Lysate from A. tumefaciens strain C58-C9 cured of the Ti plasmid; the cryptic plasmid is present. (C) Lysate from $R$. leguminosarum strain A171 showing three large plasmids. (D) Lysate of a non-nodulating derivative of $R$. leguminosarum A171 obtained after heat treatment; the lower band corresponding to a plasmid with a molecular weight of $110 \times 10^{6}$ is absent. For (A) and (B) the lysing buffer was at pH 12.25; for (C) and (D) it was at pH 12.55 (at $21^{\circ} \mathrm{C}$ ).

intense band at the top, one, two or three bands in the middle and a trail at the bottom. The top band was mainly due to DNA and could be eliminated by treating the sample with $H$ indIII restriction endonuclease before electrophoresis. It was probably the open circular (OC) plasmid DNA which is known to migrate considerably more slowly than CCC-DNA (Aaij \& Borst, 1972; Greene et al., 1974) and which, in the case of large plasmids, probably cannot enter the gel. The lower trail was made up of linear DNA and contained both chromosomal DNA and linear plasmid DNA. Intermediate bands corresponded to CCCDNA molecules (Meyers et al., 1976).

The distribution of the three forms of the large plasmid DNA in the agarose gel was confirmed with DNA of pRme-L5-30 purified by CsCl-EtBr ultracentrifugation, dialysed for $2 \mathrm{~d}$ and then submitted to agarose gel electrophoresis. In addition to the CCC form, a prolonged dialysis should generate $\mathrm{OC}$ and linear forms for such a large plasmid. As expected, there was a strong fluorescent band at the top, which was sensitive to HindIII restriction endonuclease and was probably due to OC-DNA. One lower band of linear plasmid DNA was found in the same place as the trail observed in crude extract experiments. For large plasmids, the $\mathrm{OC}$ forms are in the very top of the gel and cannot be confused with CCC-DNA, as is the case of very small plasmids for which OC forms can enter the gel (Aaij \& Borst, 1972). Therefore each band in the gel should correspond to a different CCC-DNA.

Only one CCC-DNA band was observed in extracts from strains L5-30 or 41 and two bands were observed in L5-30 (RP4). The location of the different CCC-DNA bands was consistent with that expected if the electrophoretic mobility of CCC-DNA molecules was inversely correlated with their molecular weight, as shown previously by Meyers et al. (1976). Surprisingly, two bands were observed with extracts of strain C58 (Fig. 1, lane A). The lower band corresponded to the Ti plasmid with a molecular weight of about $120 \times 10^{6}$ (Van Larebeke et al., 1974; Watson et al., 1975). The upper one could be either a larger 


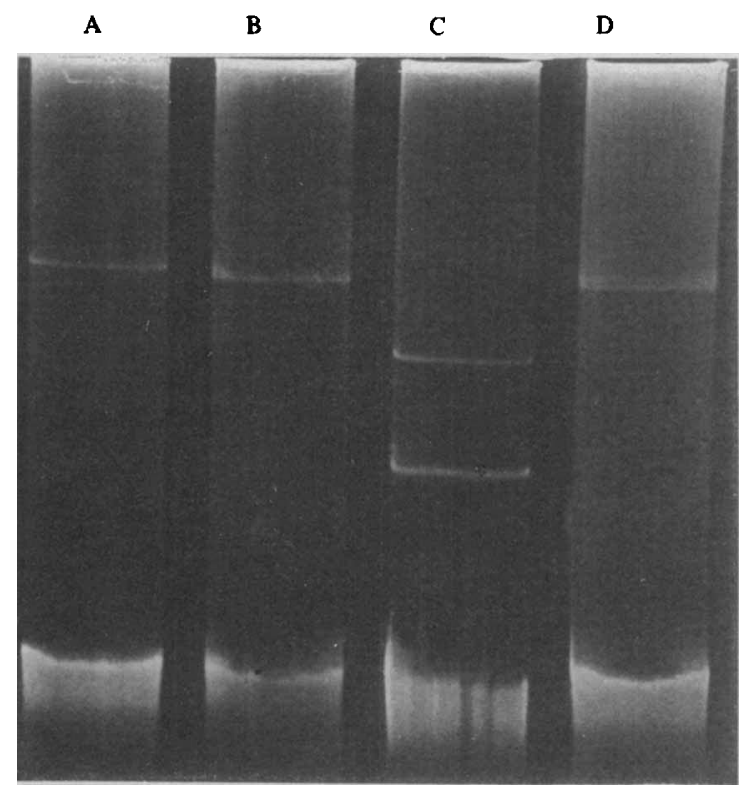

Fig. 2. Agarose gel electrophoresis of very large plasmids from Pseudomonas putida. (A) Lysate from $P$. putida strain PpS1239 carrying plasmid pMG1 (mol. wt $312 \times 10^{6}$; Hansen \& Olsen, 1978). (B) Lysate from $P$. putida strain PpS1240 carrying plasmid pMG5 (mol. wt $280 \times 10^{6}$; Hansen \& Olsen, 1978). (C) Lysate from $R$. meliloti strain L5-30 (RP4) with the reference plasmids pRme-L5-30 (mol. wt $91 \times 10^{6}$ ) and RP4 (mol. wt $36 \times 10^{6}$ ). (D) A mixture of lysates from $P$. putida strains PpS1239 and PpS1240 showing the separation of plasmids pMG1 and pMG5.

plasmid or the OC form of the Ti plasmid itself. For further identification of these bands, an electrophoresis gel was run with strain $\mathrm{C} 58-\mathrm{C} 9$, a $\mathrm{C} 58$ derivative cured of the Ti plasmid (Bomhoff et al., 1976). In Fig. 1 (lane B) it can be seen that the lower band corresponding to Ti was absent while the upper band was still present. Therefore this band does not correspond to the $\mathrm{OC}$ form of $\mathrm{Ti}$ but is due to another, probably very large, plasmid which could not be detected by the methods described previously by Zaenen et al. (1974), Ledeboer et al. (1976) and Currier \& Nester (1976).

Agarose gel electrophoresis was then used to examine crude extracts of three Rhizobium strains ( $R$. leguminosarum LPR 115 and A171 and $R$. trifolii RCR5) in which sedimentation profiles in alkaline sucrose gradient followed by reassociation kinetic studies suggested the presence of plasmids of unusually high molecular weight (Nuti et al., 1977; Prakash et al., 1979). Agarose gel electrophoresis showed CCC-DNA bands of very low relative mobility in these strains (see Fig. 1, lane C). After heat treatment of $R$. leguminosarum A171 cultures, rough derivatives could be isolated (Prakash et al., 1979) which lacked the lower band. The two upper bands were still present showing that they do not correspond to the OC form of the cured plasmid (Fig. 1, lanes $\mathrm{C}$ and D). We also examined crude extracts of two Pseudomonas putida strains carrying the very large plasmids pMG1 and pMG5, which were estimated by contour length measurements to have molecular weights of $312 \times 10^{6}$ and $280 \times 10^{6}$, respectively (Hansen \& Olsen, 1978). Agarose gel electrophoresis clearly showed CCC-DNA bands of very low mobility (Fig. 2). The upper bands found in A. tumefaciens $\mathrm{C} 58$ and $R$. leguminosarum $\mathrm{A} 171$ had a relative mobility lower than that of pMG1 suggesting the presence in these strains of plasmids of molecular weights higher than $300 \times 10^{6}$.

Agarose gel electrophoresis shows a high resolution of CCC-DNA of large plasmids with similar molecular weights. For example, two plasmids of about $125 \times 10^{6}$ were detected in $A$. tumefaciens B6-806 by Sciaky et al. (1978) - a Ti plasmid and an additional cryptic 
A

B

$\mathrm{C}$

D E

$\mathbf{F}$

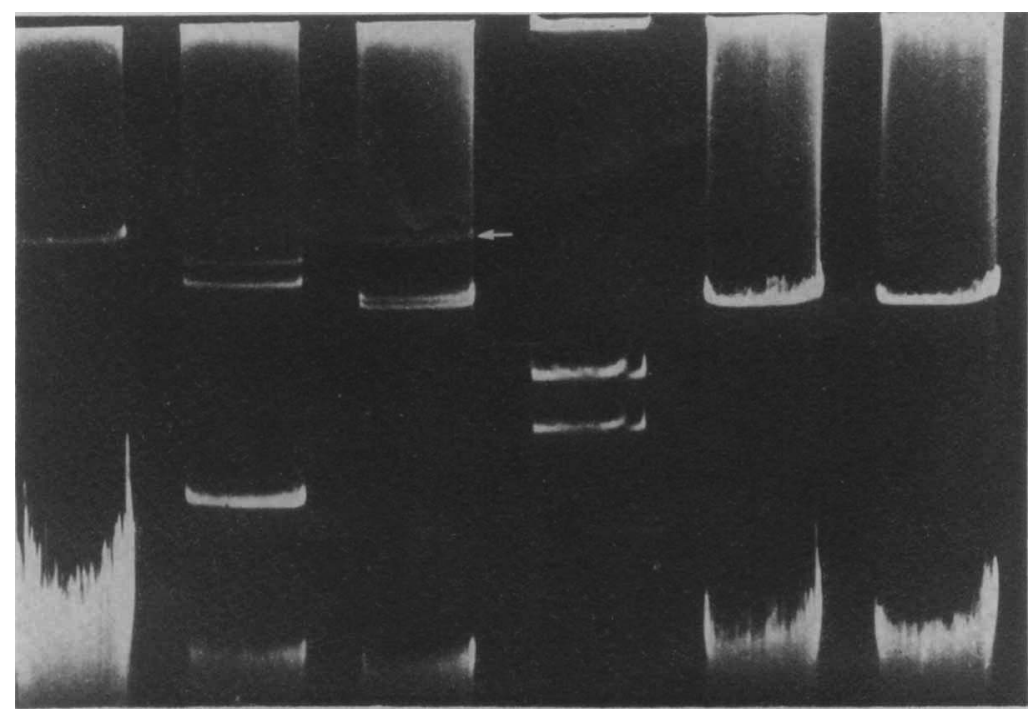

Fig. 3. Agarose gel electrophoresis of ethanol-precipitated DNA from crude lysates of $A$. tumefaciens and $R$. meliloti strains. (A) Lysate of $A$. tumefaciens strain C58-C9, cured of the Ti plasmid, showing a very large cryptic plasmid. The lysing buffer was at pH $12 \cdot 40$ (at $21^{\circ} \mathrm{C}$ ); chromosomal DNA is abundant and the large plasmid band is clear. (B) and (C) Lysates of $A$. tumefaciens strains 0362 and B6-806, respectively. The lysing buffer was at $\mathrm{pH} 12.65$ (at $21^{\circ} \mathrm{C}$ ); the amount of linear DNA is low allowing detection of a small plasmid in strain 0362 but the yield of the very large plasmid of B6-806 (arrowed) is very low. The two plasmids of B6-806 with molecular weights of about $125 \times 10^{6}$ are separated. (D) Purified CCC-DNA molecules of RP4 (mol. wt $36 \times 10^{6}$ ) and pGMI 165C (mol. wt $46 \times 10^{6}$ ). (E) and (F) Lysates of $R$. meliloti strains U45 and 102F51, respectively. The lysing buffer was at $\mathrm{pH} 12 \cdot 55$ (at $21^{\circ} \mathrm{C}$ ).

plasmid. These plasmids, which have similar molecular weights according to contour length measurements (Sciaky et al., 1978), were separated by gel electrophoresis within $4 \mathrm{~h}$ (Fig. 3, lane $\mathrm{C})$. When crude extracts of the very large plasmids pMG1 and pMG5 $\left(312 \times 10^{6}\right.$ and $280 \times 10^{6}$ ) were mixed and run together, the two CCC-DNA bands were separated within 4 h (Fig. 2, lane D).

Fluorescence at the top of the gel (including the open circular form) represented 20 to $50 \%$ of the total fluorescence. The proportion of plasmid DNA in the supercoiled form decreased with increase in the size of the molecule: from about $12 \%$ for RP4 $\left(36 \times 10^{6}\right)$ to $8 \%$ for pRme-L5-30 $\left(91 \times 10^{6}\right)$ and less than $5 \%$ for U54 $\left(151 \times 10^{6}\right)$. It is not surprising that a high proportion of plasmids of such high molecular weight is obtained as open circular or linear DNA rather than as intact CCC-DNA. This decrease in the proportion of CCC-DNA molecules with increasing molecular weight made it necessary to increase the volume of the DNA sample loaded on to the gel to detect very large plasmids: 20 to $50 \mu \mathrm{l}$ samples had to be used rather than the 10 to $20 \mu \mathrm{l}$ samples which were sufficient for detecting plasmids with molecular weights of $90 \times 10^{6}$ to $120 \times 10^{6}$. However, overloading may deform the top of the gel (Fig. 1, lanes C and D).

The purely chemical lysis procedure, $(1 \%$ sodium dodecyl sulphate in a Tris, EDTA buffer at $\mathrm{pH}$ 12.45) was shown to be efficient for Agrobacterium, Rhizobium, Escherichia coli, Klebsiella pneumoniae, Pseudomonas mors-prunorum and P. putida. In E. coli strains carrying P group plasmids (about $64 \%$ GC), the amount of linear chromosomal DNA was much reduced and so the linear plasmid DNA band was apparent in some experiments. This could be due to the low GC content of the E. coli chromosomal DNA ( $50 \%$ GC) making it more sensitive to alkaline denaturation than Rhizobium meliloti or Agrobacterium 


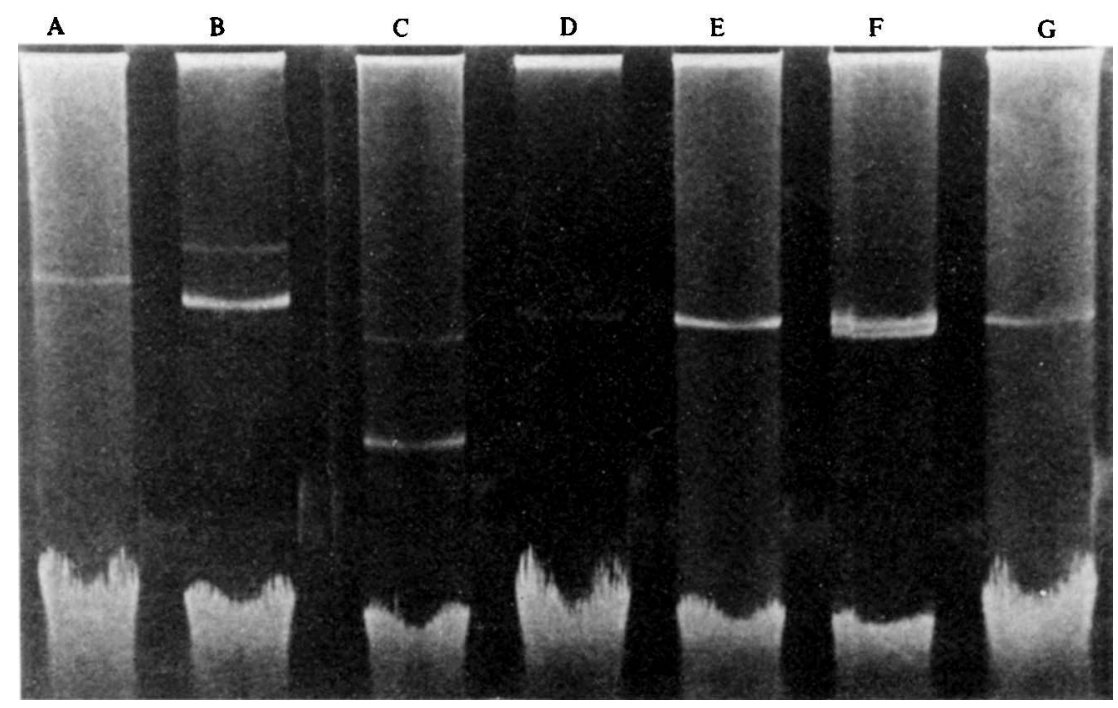

Fig. 4. Agarose gel electrophoresis of ethanol-precipitated DNA from crude lysates of $A$. tumefaciens strain C58 (B) and $R$. meliloti strains U54 (A), L5-30 (RP4) (C), 12 (D), U45 (E), Ve8 (F) and 102F51 (G).

chromosomal DNA (62\% GC). In eight $P$. mors-prunorum strains, numerous plasmids could be detected with molecular weights ranging from $2 \times 10^{6}$ to $120 \times 10^{6}$, as confirmed by electron microscopy studies (J. P. Prunier \& C. Boucher, personal communication), showing that as expected the extraction procedure is suitable for plasmids of various sizes including very small ones. The detection of very small plasmids in numerous strains of $P$. mors-prunorum suggests that the lack of detection of such plasmids in the $R$. meliloti strains subsequently investigated is not due to a limitation of the method. Nevertheless, one limitation of the crude extract electrophoresis technique is that contamination with linear DNA can mask CCC-DNA of molecular weight ranging between $7 \cdot 5 \times 10^{6}$ and $15 \times 10^{6}$ (Meyers et al., 1976).

\section{Screening for plasmids in $R$. meliloti}

The $25 R$. meliloti strains listed in Table 1 included (i) bacteria of various geographical origins (Africa, Oceania, North and South America and Europe), (ii) commercial strains from U.S.A. (102F28, 102F51, S26, S33), Australia (RCR2011 = SU47), South America (U45), France (Sa10) and very efficient strains selected in Canada (Balsac, S14), and (iii) strains which have already been studied genetically (L5-30, RCR2011, 41, 102F51). At least three DNA extractions were performed for each strain. On each gel, DNA from strain L5-30 (RP4) was used as a reference (Fig. 4). Bands corresponding to CCC-DNA of molecular weights higher than $90 \times 10^{6}$ (that is of relative mobility similar to or lower than that of pRme-L5-30) were found in 22 strains. Eight strains showed more than one CCCDNA band: Ve8, RF22, Balsac, Ls2a, S14, 311, I1 and 102F28. The relative electrophoretic mobilities of the 30 plasmids detected were calculated using pRme-L5-30 as a standard (Table 2). In previous experiments with a $5 \mathrm{~min}$ phenol extraction, no CCC-DNA could be detected in strains $\mathrm{Sa} 10$ and $\mathrm{Lb} 1$; detection was possible with $2 \mathrm{~min}$ phenol extractions.

No plasmids were detected in strains RCR2011, S26 and A145. This could be due to a procedural limitation because a plasmid with a molecular weight of about $260 \times 10^{6}$ has been detected in strain RCR2011 by alkaline sucrose gradient centrifugation followed by reassociation kinetics (M. Nuti, personal communication) and by neutral sucrose gradient centrifugation followed by electron microscopy (A. Pühler, personal communication). It is not clear why the procedure that easily allows the detection of plasmids with molecular 
Table 2. Molecular weight determinations of plasmids by agarose gel electrophoresis and contour length measurements

\begin{tabular}{|c|c|c|c|c|c|}
\hline \multirow[b]{2}{*}{ Strain } & \multirow[b]{2}{*}{$\begin{array}{c}\text { Plasmid } \\
\text { designations }\end{array}$} & \multicolumn{2}{|c|}{ Gel electrophoresis } & \multicolumn{2}{|c|}{ Electron microscopy } \\
\hline & & $\begin{array}{l}\text { Relative } \\
\text { mobility }\end{array}$ & $\begin{array}{l}10^{-6} \times \\
\text { Mol. wt }\end{array}$ & $\begin{array}{c}\text { Contour length } \dagger \\
(\mu \mathrm{m})\end{array}$ & $\begin{array}{l}10^{-6} \times \\
\text { Mol. wt }\end{array}$ \\
\hline
\end{tabular}

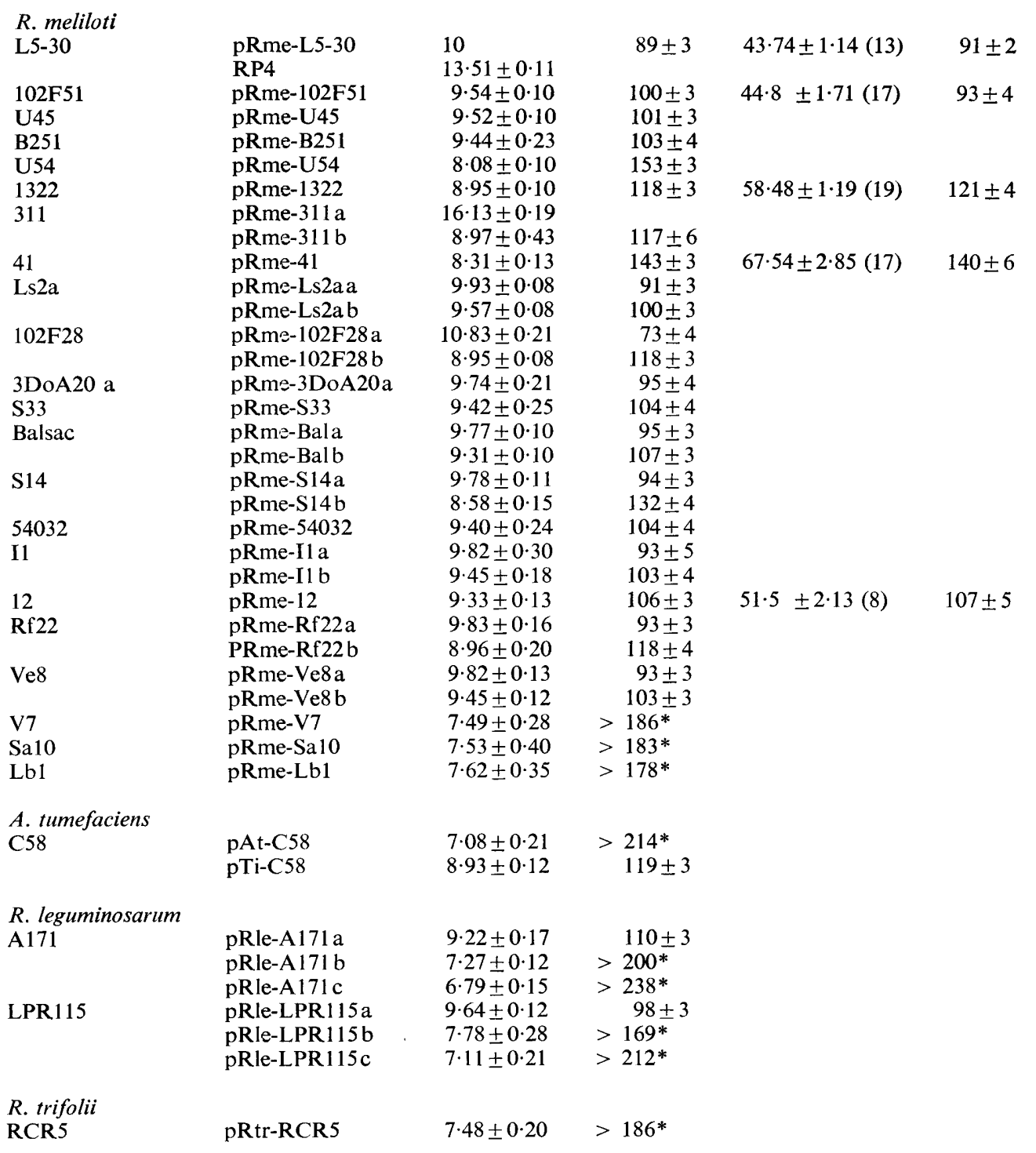

* Molecular weight estimated from the regression straight line but outside the interval in which linearity was shown.

$\dagger$ Number of molecules measured is indicated in parentheses. 


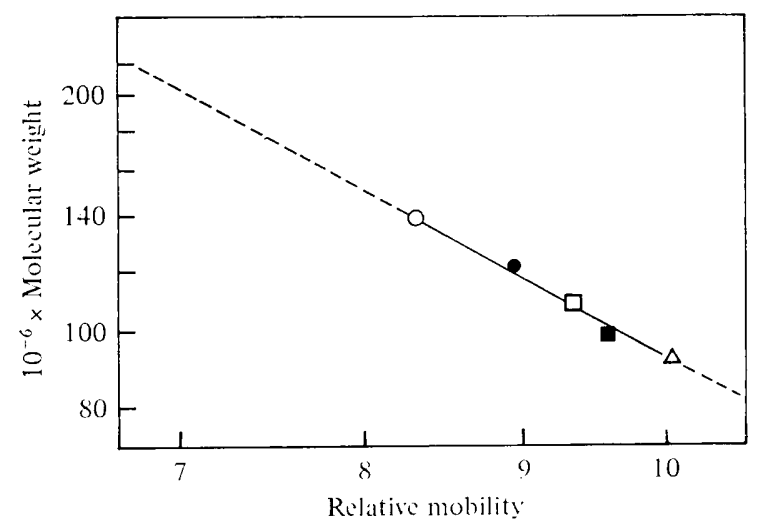

Fig. 5. Molecular weight (MW) versus relative mobility (RM) for plasmid DNA of known molecular weight from Rhizobium meliloti: $\triangle$, pRme-L5-30 $\left(91 \times 10^{6}\right) ; \square$, pRme-102F51 $\left(93 \times 10^{6}\right) ; \square$, pRme-12 $\left(107 \times 10^{6}\right)$;, , pRme-1322 $\left(121 \times 10^{6}\right) ; \bigcirc$, pRme-41 $\left(140 \times 10^{6}\right)$ - — in the interval where linearity was shown; - _ , extrapolation of the linear curve. The equation of the regression line is: $\log \mathrm{MW}=-2.54 \log \mathrm{RM}+4.49 ; r=-0.98$.

weights of $280 \times 10^{6}$ and $310 \times 10^{6}$ in $P$. putida and of very large plasmids of similar molecular weight in R. leguminosarum A171 and LPR 115 and $A$. tumefaciens does not detect a plasmid of about $260 \times 10^{6}$ in $R$. meliloti RCR2011. Degradation by nucleases is unlikely because lysis is performed at very high $\mathrm{pH}$ for $25 \mathrm{~min}$ followed by a phenol extraction and also because plasmid RP4 recovery is as efficient from strain RCR2011 as from strain L5-30.

\section{Estimation of plasmid molecular weights}

Meyers et al. (1976) have shown that the estimation of plasmid molecular weights from the extent of CCC-DNA migration in agarose gels compares favourably with results obtained by electron microscopy of plasmid DNA purified by $\mathrm{CsCl}-\mathrm{EtBr}$ equilibrium density centrifugation. A plot of the logarithm of relative migration through the gel against the logarithm of plasmid molecular weight determined by electron microscopic and physical measurements provided a consistent linear curve for plasmids ranging in molecular weight from $1.87 \times 10^{6}$ to $93.2 \times 10^{6}$. We wanted to know if the same correlation was applicable for plasmids of molecular weight higher than $90 \times 10^{6}$.

In addition to strains L5-30 and 41 already studied, three other strains showing only one CCC-DNA band in gels with different relative electrophoretic mobilities were chosen for electron microscopic studies: 12, 1322 and 102F51. Contour length measurements o the plasmids and estimated molecular weights are given in Table 2. In Fig. 5, the logarithm of relative mobility of the CCC-DNA band (mean of three gels) is plotted against the logarithm of molecular weight determined by contour length measurements for the five plasmids: pRme-L5-30, pRme-102F51, pRme-12, pRme-1322 and pRme-41. The molecular weights of the five plasmids range between $91 \times 10^{6}$ and $140 \times 10^{6}$. The logarithm of relative mobility (RM) was correlated to the logarithm of molecular weight (MW) and a linear relationship was obtained. Calculation of the linear correlation coefficient gave $r=-0.98$ and the equation of the regression line shown in Fig. 5 is:

$$
\log \mathrm{MW}=-2.54 \log \mathrm{RM}+4 \cdot 49
$$

This equation was used to calculate the molecular weights of the large plasmids of the different strains investigated (Table 2). The standard deviation of calculated molecular weights takes into account deviation of the measured relative mobility and the error calculated from the regression line.

Of the 30 plasmids of $R$. meliloti investigated, 24 fell within the interval where linearity 
was observed $\left(90 \times 10^{6}\right.$ to $\left.140 \times 10^{6}\right)$. For these plasmids, molecular weight estimations should be reliable. For instance, the molecular weight of the Ti plasmid of $A$. tumefaciens C58 was estimated by agarose gel electrophoresis to be $119 \times 10^{6}$, which is consistent with the molecular weight of $120 \times 10^{6}$ obtained from contour length measurements (Currier \& Nester, 1976). On the other hand, for plasmids of more than $140 \times 10^{6}$, molecular weights were calculated by a linear extrapolation of the curve obtained in the interval $90 \times 10^{6}$ to $140 \times 10^{6}$, which could cause considerable underestimation of molecular size. For instance, the molecular weight of the plasmid pRme-V7 was estimated to be $186 \times 10^{6}$ by gel electrophoresis and $197 \times 10^{6}$ by electron microscopy. The underestimation could be much higher for larger plasmids. Recently Hansen \& Olsen (1978) reported that for the very large plasmids pMG1 and pMG5 $\left(312 \times 10^{6}\right.$ and $280 \times 10^{6}$, respectively) agarose electrophoresis under similar conditions gave underestimates. Therefore in Table 2, for plasmids of molecular weight higher than $140 \times 10^{6}$, values should be considered as minima rather than an exact determination of molecular weight. Such is the case for plasmids pRme-Lb1 and $\mathrm{pRme-Sa} 10$ of $R$. meliloti, pRle-A171 b and c and pRle-LPR $115 \mathrm{~b}$ and $\mathrm{c}$ of $R$. leguminosarum, pRtr-RCR5 of $R$. trifolii and pAT-C58 of A. tumefaciens.

It is noteworthy that all the plasmids detected in the Rhizobium species have molecular weights higher than $90 \times 10^{6}$ with only two exceptions: strains 311 and 102 F28 carry an additional smaller plasmid of molecular weight less than $30 \times 10^{6}$ and $73 \times 10^{6}$, respectively. No very small plasmid suitable as a cloning vehicle for genetic engineering was found.

\section{Concluding remarks}

The presence of plasmids of molecular weight higher than $90 \times 10^{6}$ seems to be a general feature in Rhizobium. These large plasmids were overlooked in earlier studies (Tshitenge et al., 1975; Dunican et al., 1976; Olivares et al., 1977) because the cleared lysate procedure for plasmid DNA isolation (Clewell \& Helinski, 1969) was used.

If we assume that the Rhizobium chromosome is of a size similar to that of E. coli or $P$. aeruginosa, the amount of extrachromosomal genetic information is significant (from 3 to more than $10 \%$ ). It is now obvious that future Rhizobium breeding for legume inoculation will require not only chromosomal hybridization (Kondorosi et al., 1977; Meade \& Signer, 1977; Beringer et al., 1978) but also plasmid transfer and recombination.

The $R$. leguminosarum strain A171, after heat treatment, yields non-nodulating derivatives, which have lost a plasmid with a molecular weight of $110 \times 10^{6}$ (Prakash et al., 1979), suggesting that this plasmid could play a role in the control of nodule-inducing ability. High frequency transfer of nodulating ability recently observed by Johnston et al. (1978) using drug resistance transposon $T n 5$ suggests a plasmid involvement in host specificity of R. leguminosarum 300.

Understanding the biological significance of plasmids will require further genetic studies using plasmid curing and transfer and plasmid mutation by insertion of transposons. It is hoped that the plasmid detection and characterization procedure described in this study will provide simple physical chemical complements to these genetic experiments. In ecological and genetic studies this efficient screening procedure will permit examination of a large number of strains of other bacteria carrying large plasmids, namely Agrobacterium and Pseudomonas species.

We thank all those who provided bacterial strains. We also acknowledge Pierre Boistard for helpful discussions, Dr J. E. Beringer and Dr A. H. Gibson for their critical reading of the manuscript and Mrs E. Michon for technical advice on electron microscopy. This work was supported by grant no. 414 from the Plant Protein Programme of the Commission of the European Communities and grant 787448 of the Délégation Générale à la Recherche Scientifique et Technique. 


\section{REFERENCES}

AAIJ, C. \& Borst, P. (1972). The gel electrophoresis of DNA. Biochimica et biophysica acta 269, 197200.

BERINGER, J. E. (1974). R factor transfer in Rhizobium leguminosarum. Journal of General Microbiology 84, 188-198.

Beringer, J. E., Hoggan, S. A. \& Johnston, A. W. B. (1978). Linkage mapping in Rhizobium leguminosarum by means of $\mathrm{R}$ plasmid-mediated recombination. Journal of General Microbiology 104, 201-207.

Bomhoff, G., KLAPwiJk, P. M., Kester, H. C. M., Schilperoort, R. A., Hernasteens, J. P. \& SCHELL, J. (1976). Octopine and nopaline synthesis and breakdown genetically controlled by a plasmid of Agrobacterium tumefaciens. Molecular and General Genetics 145, 177-181.

Bordeleau, L. M., Antoun, H. \& Lachance, R. A. (1977). Effets des souches de Rhizobium meliloti et des coupes successives de la luzerne (Medicago sativa) sur la fixation symbiotique d'azote. Canadian Journal of Plant Science 57, 433-439.

Boucher, C., Bergeron, B., Barate de Bertalmio, M. \& DÉNARIÉ, J. (1977). Introduction of bacteriophage $\mathrm{Mu}$ into Pseudomonas solanacearum and Rhizobium meliloti using the $\mathbf{R}$ factor RP4. Journal of General Microbiology 98, 253-263.

Brockwell, J. \& Hely, F. W. (1966). Symbiotic characteristics of Rhizobium meliloti: an appraisal of the systematic treatment of nodulation and nitrogen fixation interactions between hosts and rhizobia of diverse origins. Australian Journal of Agricultural Research 17, 885-899.

Clewell, D. B. \& Helinski, D. R. (1969). Supercoiled circular DNA-protein complex in Escherichia coli: purification and induced conversion to an open circular DNA form. Proceedings of the National Academy of Sciences of the United States of America 62, 1159-1166.

CuRrier, T. C. \& Nester, E. W. (1976). Isolation of covalently closed circular DNA of high molecular weight from bacteria. Analytical Biochemistry 76, 431-441.

Datta, N., Hedges, R. W., Shaw, E. J., Sykes, R. B. \& Richmond, M. H. (1971). Properties of an $\mathrm{R}$ factor from Pseudomonas aeruginosa. Journal of Bacteriology 108, 1244-1249.

Dénarié, J., Truchet, G. \& Bergeron, B. (1976). Effects of some mutations on symbiotic properties of Rhizobium. In Symbiotic Nitrogen Fixation in Plants, pp. 47-61. Edited by P.S. Nutman. Cambridge: Cambridge University Press.

Dunican, L. K., O'Gara, F. \& Tierney, A. B. (1976). Plasmid control of effectiveness in Rhizobium: transfer of nitrogen-fixing genes on a plasmid from Rhizobium trifolii to Klebsiella aerogenes. In Symbiotic Nitrogen Fixation in Plants, pp. 77-90. Edited by P.S. Nutman. Cambridge: Cambridge University Press.

Gasser, H., Guy, P., Obaton, M. \& Sikora, I. (1972). Efficiency of Rhizobium meliloti strains and their effects on alfalfa cultivars. Canadian Journal of Plant Science 52, 441-448.

Greene, P. J., Betlach, M. G., Boyer, H. W. \&
Goodman, H. M. (1974). The Eco R1 restriction endonuclease. Methods in Molecular Biology 7, 87-105.

Guerry, P., Le Blanc, D. J. \& Falkow, S. (1973). General method for the isolation of plasmid deoxyribonucleic acid. Journal of Bacteriology 116, 1064-1066.

HANSEN, J. B. \& Olsen, R. H. (1978). Isolation of large bacterial plasmids pMG1 and pMG5. Journal of Bacteriology 135, 227-238.

Hanson, C. H. (1972). Alfalfa Science and Technology. Madison, U.S.A.: American Society of Agronomy.

Humphreys, G. O., Willshaw, G. A. \& Anderson, E. S. (1975). A simple method for the preparation of large quantities of pure plasmid DNA. Biochimica et biophysica acta 383, 457-463.

Johnston, A. W. B., Beynon, J. L., BuChaNANWollaston, A. V., Setchell, S. M., Hirsch, P. R. \& Beringer, J. E. (1978). High frequency transfer of nodulating ability between strains and species of Rhizobium. Nature, London 276, 634 636.

Kondorosi, A., Kiss, G. B., Forrai, T., Vincze, E. \& Banfalvi, Z. (1977). Circular linkage map of the Rhizobium meliloti chromosome. Nature, London 268, 525-527.

KowALSKI, M. (1970). Transducing phages in Rhizobium meliloti. Acta microbiologica polonica, Ser. A 2, 109-114.

Ledeboer, A. M., Krol, A. J. M., Dons, J. J. M., SPIER, F., Schilperoort, R. A., Zaenen, I., VAN LAREBEKE, N. \& SCHELL, J. (1976). On the isolation of Ti plasmid from Agrobacterium tumefaciens. Nucleic Acids Research 3, 449-463.

Meade, H. M. \& Signer, E. R. (1977). Genetic mapping of Rhizobium meliloti. Proceedings of the National Academy of Sciences of the United States of America 74, 2076-2078.

Meyers, J. A., Sanchez, D., Elwell, L. P. \& Falkow, S. (1976). Simple agarose gel electrophoretic method for the identification and characterization of plasmid deoxyribonucleic acid. Journal of Bacteriology 127, 1529-1537. [Erratum (1977), Journal of Bacteriology 129, 1171.]

Nuti, M. P., Ledeboer, A. M., LePIdi, A. A. \& SCHILPEROORT, R. A. (1977). Large plasmids in different Rhizobium species. Journal of General Microbiology 100, 241-248.

Olivares, J., Montaya, E. \& Palomares, A. (1977). Some effects derived from the presence of extrachromosomal DNA in Rhizobium meliloti. In Recent Developments in Nitrogen Fixation, pp. 375-385. Edited by W. Newton, J. R. Postgate \& C. Rodriguez-Barrueco. London: Academic Press. Prakash, R. K., HooykaAs, P. J. J., Ledeboer, A. M., KiJne, J., Schilperoort, R. A., Nuti, M. P., Lepidi, A. A., Casse, F., Boucher, C., Julliot, J. S. \& DéNARIÉ, J. (1979). Detection, isolation and characterization of large plasmids in Rhizobium. In Proceedings of the 3rd International Symposium on Nitrogen Fixation (in the Press). Edited by W. E. Newton \& W. H. OrmeJohnson. Madison: University Park Press. 
Radloff, R., Bauer, W. \& Vinograd, J. (1967). A dye-buoyant-density method for the detection and isolation of closed circular duplex DNA. Proceedings of the National Academy of Sciences of the United States of America 57, 1514-1521.

Sciaky, D., Montoya, A. L. \& Chilton, M. D. (1978). Fingerprints of Agrobacterium Ti plasmids. Plasmid 1, 238-253.

Sváb, Z., Kondorosi, Á. \& Orosz, L. (1978). Specialized transduction of a cysteine marker by Rhizobium meliloti phage 16-3. Journal of General Microbiology 106, 321-327.

Tshitenge, G., Luyindula, N., Lurquin, P. F. \& LEDOuX, L. (1975). Plasmid DNA in $R$. vigna and R. trifolii. Biochimica et biophysica acta 414, 357-361.

VAN Larebeke, N., Engler, G., Holsters, M.,
VAn Den Elsacker, S., Zaenen, I., Schil peroort, R. A. \& SCHELl, J. (1974). Large plasmid in Agrobacterium tumefaciens essential for crowngall inducing ability. Nature, London 252, 169-170.

Vincent, J. M. (1970). A Manual for the Practical Study of Root-nodule Bacteria, IBP Handbook no. 15. Oxford and Edinburgh: Blackwell Scientific Publications.

Watson, B., Currier, T. C., Gordon, M. P., Chilton, M. D. \& Nester, E. W. (1975). Plasmid required for virulence of Agrobacterium tumefaciens. Journal of Bacteriology 123, 255-264.

Zaenen, I., VAN LaRebeke, N., Teúchy, H., VAN Montagu, M. \& Schell, J. (1974). Supercoiled circular DNA in crown-gall inducing Agrobacterium strains. Journal of Molecular Biology 86, 109-127. 